\title{
PELAKSANAAN PENJARINGAN DETEKSI DINI KASUS KANKER LEHER RAHIM DENGAN TES INSPECTION VISUAL ASAM ACETAT (IVA) DI MASA PANDEMIC COVID-19
}

\author{
Eneng Daryanti ${ }^{1}$, Meti Sulastri ${ }^{2}$ \\ Universitas Bhakti Kencana Tasikmalaya ${ }^{\mathbf{1 , 2}}$ \\ eneng.daryanti@bku.ac.id
}

\begin{abstract}
ABSTRAK
Sekitar $80 \%$ kasus kanker leher rahim terjadi pada wanita usia subur yang hidup di negara berkembang. Di Indonesia terdapat sekitar 90 - 100 kasus kanker leher rahim per 1.000 penduduk. Kanker leher rahim adalah kematian nomor satu yang sering terjadi pada wanita di Indonesia. Pada umumnya rentang umur penderita kanker leher rahim adalah 30-60 tahun, namun insiden tertinggi pada rentang umur 35 - 55 tahun. Saat ini usia remaja juga berisiko terkena kanker leher rahim, ini disebabkan karena remaja mulai berhubungan seksual pada usia di bawah 18 tahun serta sering berganti-ganti pasangan, ini akan berisiko tinggi terkena infeksi virus HPV. Semua wanita yang berusia 18 tahun atau lebih dan telah aktif secara seksual harus melakukan papsmear. Semakin dini sel-sel abnormal dideteksi semakin rendah risiko wanita menderita kanker leher rahim. Jenis penelitian yang digunakan dalam penelitian ini adalah jenis penelitian deskriptif, dengan menggunakan analisa univariat. Berdasarkan hasil penelitian dan pembahasan, maka dapat disimpulkan bahwa tes Inspeksi Visual Asam Asetat (IVA) dapat menjaring kasus kanker leher rahim di Wilayah Kerja Puskesmas Rancah Kota Banjar tahun 2020. Disarankan bagi petugas kesehatan untuk lebih proaktif dalam memberikan informasi kepada masyarakat mengenai bahaya kanker leher rahim, sehingga masyarakat awam dapat mengetahuinya.
\end{abstract}

Kata kunci: deteksi dini, kanker leher rahim, IVA test, penjaringan

\begin{abstract}
About $80 \%$ of cervical cancer cases occur in women of childbearing age living in developing countries. In Indonesia, there are about 90-100 cases of cervical cancer per 1,000 population. Cervical cancer is the number one death that often occurs in women in Indonesia. In general, the age range of patients with cervical cancer is 30-60 years, but the highest incidence is in the age range of 35-55 years. Currently teenagers are also at risk of cervical cancer, this is because teenagers start having sex at the age of under 18 years and often change partners, this will be at high risk of infection with the HPV virus. All women who are 18 years of age or older and are sexually active should have a pap smear. The earlier abnormal cells are detected, the lower the risk of women suffering from cervical cancer. The type of research used in this research is descriptive research, using univariate analysis. Based on the results of research and discussion, it can be concluded that the Visual Inspection of Acetic Acid (IVA) test can capture cases of cervical cancer in the Work Area of the Rancah Health Center, Banjar City in 2020. It
\end{abstract}


is recommended for health workers to be more proactive in providing information to the public about the dangers of neck cancer. womb, so that the general public can know about it.

\section{Keywords: early detection, cervical cancer, IVA test, screening}

\section{PENDAHULUAN}

Kanker leher rahim merupakan kanker yang terbanyak diderita wanita-wanita di negara yang sedang berkembang termasuk di Indonesia. Kanker leher rahim ini menduduki urutan kedua penyakit kanker di dunia bahkan sekitar 500.000 wanita di seluruh dunia di diagnosa menderita kanker leher rahim dan rata-rata 270.000 meninggal tiap tahun. Sebagaimana kanker pada umumnya maka kanker serviks menimbulkan masalahmasalah berupa kesakitan (morbiditas), penderitaan, kematian, finansial/ekonomi maupun lingkungan bahkan pemerintah (Widiyanti, 2013). Pandemik covid19 mengakibatkan keterbatasan kunjungan masyarakat ketenaga kesehatan, yang mengakibatkan kesadaran dan kewaspadaan masyarakat akan pentingnya deteksi dini kanker leher srviksmenjadi berkurang. menyebabkan World Health Organization (WHO) menyatakan bahwa sekitar sepertiga kanker dapat disembuhkan jika didiagnosis dan ditangani pada stadium dini, untuk itu diagnosis skrining kanker mutlak dilakukan. Teknik skrining yang dapat dilakukan untuk menjaring kanker leher rahim adalah pap smear dan tes IVA (Sundari \& Setiawati, 2018).
Sekitar $80 \%$ kasus kanker leher rahim terjadi pada wanita usia subur yang hidup di negara berkembang. Di Indonesia terdapat sekitar 90 - 100 kasus kanker leher rahim per 1.000 penduduk. Kanker leher rahim adalah kematian nomor satu yang sering terjadi pada wanita di Indonesia . Kanker leher rahim disebabkan oleh Human Papiloma Virus (HPV). Menurut Bambang (2008) mengatakan kaum lelaki berperan sangat besar dalam penularan HPV. Laki-laki yang suka berganti-ganti pasangan berisiko menularkan virus papiloma dari pasangannya yang menderita kanker leher rahim ke pasangannya yang baru (Riyadini, 2016). Di Jawa Barat pada tahun 2016 sebanyak 2076 kasus atau sekitar 19,70\%. Profil kesehatan 2018 menyebutkan bahwa penyakit kanker leher rahim adalah 19,70\% per 10.000 penduduk. Berdasarkan laporan dari Yayasan Kanker Indonesia (YKI) Kota Banjar pada tahun 2019 kasus penyakit leher rahim ditemukan sebanyak 500 kasus (6-7\%) dari 8000 orang yang diperiksa. Khususnya di Wilayah Puskesmas Rancah Kota Banjar ditemukan 8 kasus (11\%) dari 73 orang yang diperiksa.

Mengingat tingginya angka kejadian serta angka kematian pada penderita kanker leher rahim serta kenyataan bahwa sebagian besar 
kasus ditemukan pada stadium lanjut, maka yang seharusnya dilaksanakan lebih baik adalah pencegahan dan deteksi dini atau skrining. Pendekatan teknologi untuk program skrining dilakukan dengan menggunakan teknologi sederhana yaitu Visual langsung Infeksi langsung dengan Asam Asetat (IVA). Efektivitas dengan program skrining ini insidens bisa turun 70-90\% (Mirzanie et al., 2019).

IVA adalah salah satu tes untuk mengidentifikasi lesi prekanker. Caranya adalah dengan mengusapkan pada leher rahim asam asetat 3-5\% dengan aplikator kapas lesi pre-kanker, lalu hasilnya diamati dengan mata telanjang selama 20-30 detik. Lesi pre-kanker positif apabila terlihat secara temporer berwarna

lebih putih dari sekitarnya (Amelia et al., 2018).

Berdasarkan latar belakang tersebut dan tingginya jumlah wanita menderita kanker leher rahim penulis tertarik untuk meneliti lebih jauh tentang "Pelaksanaan Penjaringan Kasus Kanker Leher Rahim dengan Tes Inspection Visual Asam Acetat (IVA) di Masa pandemic covid-19 di Wilayah Kerja Puskesmas Rancah Banjar".

\section{METODE PENELITIAN}

Jenis penelitian yang digunakan dalam penelitian ini adalah jenis penelitian deskriptif. Populasi dalam penelitian ini adalah seluruh WUS dari PUS yang berada di Wilayah Kerja Puskesmas Rancah Kota Banjar yang berjumlah 45 orang. Pada penelitian ini tidak dilakukan pengambilan sampel, jadi seluruh populasi dijadikan subjek penelitian. Variabel Penelitian ini terdiri dari variabel tunggal yaitu tes

\begin{tabular}{lcc}
\hline Tes IVA & Frekuensi & Persentase \\
\hline Negatif & 35 & 77,8 \\
Positif & 10 & 22,2 \\
Jumlah & $\mathbf{4 5}$ & $\mathbf{1 0 0}$ \\
\hline IVA untuk & menjaring & kanker leher \\
rahim. & \\
HASIL PENELITIAN \\
Tabel 1 \\
Distribusi Frekuensi Tes IVA \\
dalam Penjaringan Kanker Leher \\
\multicolumn{3}{c}{ Rahim }
\end{tabular}

Berdasarkan Tabel 1 menunjukkan bahwa sebagian besar WUS di Wilayah Kerja Puskesmas Rancah Kota Banjar pada saat pelaksanaan kasus kanker leher rahim dengan menggunakan Tes Inspeksi Visual Asam Asetat (IVA) sebanyak 35 orang $(77,8 \%)$ ada pada kategori negatif, sedangkan sebanyak 10 orang $(22,2 \%)$ ada pada kategori positif.

\section{PEMBAHASAN}

Berdasarkan hasil penelitian menunjukkan bahwa dari 45 responden yang dilakukan penjaringan kasus kanker leher rahim dengan menggunakan tes IVA sebanyak 10 orang $(22,2 \%)$ dinyatakan positif. Hal ini membuktikan bahwa tes IVA merupakan salah satu metode atau cara yang efektif dalam pelaksanaan penjaringan kasus kanker leher rahim. Ini sejalan dengan pendapat Febri (2008) yang menyatakan bahwa dengan metode inspeksi visual yang 
lebih mudah, lebih sederhana, lebih mampu laksana, maka skrining dapat dilakukan dengan cakupan lebih luas, diharapkan temuan kanker leher rahim dini akan bisa lebih banyak. Kanker serviks mengenal stadium pra-kanker yang dapat ditemukan dengan skrining sitologi yang relative murah, tidak sakit, cukup akurat, dan dengan bantuan kolposkopi, stadium ini dapat diobati dengan cara-cara konservatif seperti krioterapi, kauterisasi atau sinar laser, dengan memperhatikan fungsi reproduksi (de Sousa et al., 2020).

Dikatakan IVA positif jika ditemukan adanya area berwarna putih disertai dengan permukaan tinggi dengan batas yang jelas di sekitar zona peralihan di leher rahim. Metode IVA dapat menjadi alternatif tes Pap smear yang mudah dan praktis dilakukan karena dapat dilakukan oleh bidan praktik swasta maupun di tempat-tempat terpencil serta hanya membutuhkan alat sederhana untuk pemeriksaan ginekologi dasar. Berdasarkan hasil penelitian yang telah dilakukan, tes IVA cukup sensitive dan spesifik dalam upaya skrining kanker serviks (Amelia et al., 2018).

Terdapat empat kategori yang dapat diketahui dari hasil pemeriksaan dengan metode IVA. Pertama, IVA negatif, artinya tidak ada tanda atau gejala kanker mulut rahim atau serviks normal. Kedua, IVA radang, artinya serviks dengan radang (servisitas), atau kelainan jinak lainnya seperti polip serviks. Ketiga, IVA positif yaitu ditemukan bercak putih (aceto white epithelium).
Kelompok ini yang menjadi sasaran temuan skrining kanker serviks dengan metode IVA karena temuan ini mengarah pada diagnosis serviks prakanker. Dan keempat, IVA kanker serviks, ini pun masih memberikan harapan hidup bagi penderitanya jika masih pada stadium invasive dini (Gutnik et al., 2016).

Berdasarkan hasil laporan konsultasi WHO menyebutkan bahwa IVA dapat mendeteksi lesi tingkat pra kanker (high-Grade Precanceraus Lesions) dengan sensitivitas sekitar $66-96 \%$ dan spesifitas 64-98\%. Sedangkn nilai prediksi positif (positive predictive value) dan nilai prediksi negative (negative predictive value) masing-masing antara $10-20 \%$ dan 92-97\% (Isra et al., 2014)

Pada pemeriksaan ini, pemeriksaan dilakukan dengan cara melihat serviks yang telah diberi asam asetat 3-5\% secara inspekulo. Setelah serviks diulas dengan asam asetat, akan terjadi perubahan warna pada serviks yang dapat diamati secara langsung dan dapat dibaca sebagai normal atau abnormal. Dibutuhkan waktu satu sampai dua menit untuk dapat melihat perubahanperubahan pada jaringan epitel. Serviks yang diberi larutan asam asetat 5\% akan merespon lebih cepat daripada larutan 3\%. Efek akan menghilang sekitar 50-60 detik sehingga dengn pemberian asam asetat akan didapat hasil gambaran serviks yang normal (merah homogen) dan bercak putih (displasia) (Okunade, 2020).

Sampai saat ini telah menemukan 60 kasus prakanker dari 
13 kasus suspek kanker serviks. Temuan lain yang cukup menarik adalah ada ibu-ibu yang menolak IVA karena tidak yakin dengan hasilnya. Hal ini penting menjadi perhatian bahwa edukasi ke masyarakat harus terus memeriksakan diri. metode IVA (inspeksi Visual Asem Asetat) merupakan salah satu metode deteksi dini kanker serviks. Metode ini terbukti baik, biaya terjangkau, dan dapat dilakukan di daerah-daerah seperti Indonesia, secara luas, karena hanya memerlukan peralatan sederhana, biaya sangat terjangkau dan dapat dilakukan oleh dokter umum, bidan bahkan perawat terlatih. dari 1,4 juta kaum perempuan diharapkan dapat mendeteksi minimal $80 \%$ dari total jumlah tersebut. Namun apabila semuanya dapat terdeteksi dengan baik, maka program tersebut dinilai berjalan dengan baik (de Sousa et al., 2020).

Di Vietnam, misalnya, pemerintahnya telah memberikan program deteksi setiap tahun dalam upaya mengurangi penyakit kanker rahim. Bahkan di Malaysia, selain memberikan pengobatan juga memberikan anti virus secara gratis, sehingga penyakit kanker rahim makin berkurang (Hull1 et al., 2020). Apresiasi masyarakat terhadap program ini sangat baik, sehingga banyak permintaan dari puskesmas dan penyedia layanan kesehatan lain untuk memperpanjang program ini. Sampai saat ini telah menemukan 60 kasus prakanker dari 13 kasus suspek kanker serviks. Temuan lain yang cukup menarik adalah ada ibu-ibu yang menolak IVA karena tidak yakin dengan hasilnya. Hal ini penting menjadi perhatian bahwa edukasi ke masyarakat harus terus memeriksakan diri.

Kanker serviks merupakan salah satu kanker yang menjadi ancaman bagi perempuan di Indonesia. Di Indonesia setiap 1 jam, seorang perempuan meninggal akibat kanker serviks. Lebih dari 70 persen perempuan memeriksakan dirinya saat sudah berada pada stadium lanjut, sehingga mengakibatkan kematian, karena kanker serviks tidak menimbulkan gejala. Semua perempuan berisiko terkena kanker serviks. Kanker serviks menimbulkan beban yang sangat besar bagi kaum perempuan Indonesia. Padahal kanker ini sangat dapat dicegah. Pencegahan primer kanker serviks dilakukan dengan edukasi/sosialisasi dan vaksinasi. Pencegahan sekunder dengan deteksi dini kanker serviks untuk mengetahui dan menangani kondisi pra kanker (Bedell et al., 2020).

\section{SIMPULAN}

Berdasarkan hasil penelitian dan pembahasan, maka dapat disimpulkan bahwa tes Inspeksi Visual Asam Asetat (IVA) dapat menjaring kasus kanker leher rahim di Wilayah Kerja Puskesmas Rancah Kota Banjar.

\section{SARAN}

Disarankan bagi ibu-ibu khususnya di Wilayah Kerja Puskesmas Rancah untuk melaksanakan pemeriksaan kanker leher rahim secara rutin, agar dapat 
terdeteksi lebih awal. Dan bagi ibuibu yang positif mengalami kanker leher rahim harus segera mungkin memeriksakan ke fasilitas kesehatan atau dokter supaya dapat ditindaklanjuti lebih sebaik-baiknya.

\section{DAFTAR PUSTAKA}

Amelia, R., Fajriyah, U. N., Octaviani, D. A., Devita, R., Aspera, A., Yuliandani, F. A., Dewi, R. K., Ratri, W. K., F.Fitriani, M. Hadi, N. A., Susanti, E. M., Wijaya, P. S., Erlita, C., Putri, E., \& F.Fitriani, M. Hadi, N. A. (2018). Jurnal Kebidanan Dan Kesehatan. Jurnal Kebidanan. https://doi.org/10.26751/ijb.v2i1. 427

Bedell, S. L., Goldstein, L. S., Goldstein, A. R., \& Goldstein, A. T. (2020). Cervical Cancer Screening: Past, Present, and Future. In Sexual Medicine Reviews (Vol. 8, Issue 1). https://doi.org/10.1016/j.sxmr.20 19.09.005

de Sousa, Á. F. L., de Carvalho, H. E. F., de Oliveira, L. B., Schneider, G., Camargo, E. L. S., Watanabe, E., de Andrade, D., Fernandes, A. F. C., Mendes, I. A. C., \& Fronteira, I. (2020). Effects of COVID-19 infection during pregnancy and neonatal prognosis: What is the evidence? In International Journal of Environmental Research and Public Health. https://doi.org/10.3390/ijerph171 14176

Dinas Kesehatan Jawa Barat. (2012).
Dinas Keshatan Jawa Barat. Profil Kesehatan Indonesia. https://doi.org/0178-0000-15104-H01-P

Gutnik, L., Moses, A., Stanley, C., Tembo, T., Lee, C., \& Gopal, S. (2016). From community laywomen to breast health workers: A pilot training model to implement clinical breast exam screening in Malawi. PLoS ONE, 11(3), $1-10$. https://doi.org/10.1371/journal.p one.0151389

Hull1, R., Mbele, M., Makhafola, T., Hicks, C., Wang, S. M., Reis, R. M., Mehrotra, R., MkhizeKwitshana, Z., Kibiki, G., Bates, D. O., \& Dlamini, Z. (2020). Cervical cancer in low and middle.income countries (Review). Oncology Letters, 20(3).

https://doi.org/10.3892/ol.2020.1 1754

Isra, W. O. A., Chriswardani Suryawati, \& Kartini, A. (2014). Evaluasi Pelaksanaan Revitalisasi Posyandu dalam Penurunan Prevalensi Balita Gizi Buruk di Kota Baubau Provinsi Sulawesi Tenggara. Jurnal Manajemen Kesehatan Indonesia.

Mirzanie, H., Prawitasari, S., \& Widad, S. (2019). Pengaruh Metode Promosi Kesehatan Terhadap Pengetahuan dan Sikap Kader tentang Deteksi Dini Kanker Leher Rahim. Jurnal Kesehatan Reproduksi. https://doi.org/10.22146/jkr.4237 3 
Okunade, K. S. (2020). Human papillomavirus and cervical cancer. In Journal of Obstetrics and Gynaecology (Vol. 40, Issue $5)$.

https://doi.org/10.1080/0144361

5.2019 .1634030

Putri, S., Djamal, A., Rahmatini, R., \& Ilmiawati, C. (2015). Perbandingan Daya Hambat Larutan Antiseptik Povidone iodine dengan Ekstrak Daun Sirih terhadap Candida albicans secara In Vitro. Jurnal Kesehatan Andalas.

Putriani, Y. E. (2011). FAKTOR FAKTOR YANG MEMPENGARUHI KETERAMPILAN KADER POSYANDU DALAM MENGINTERPRETASIKAN HASIL PENIMBANGAN PADA KARTU MENUJU SEHAT (KMS). UNIVERSITAS JEMBER.

Riyadini, M. (2016). Analisis Implementasi Program deteksi dini kanker servik dengan metode inspeksi visual asam asetat (IVA) di puskesmas kota semarang tahun 2015. In Skripsi Ilmu Kesehatan Masyarakat FIK Unnes.

Sundari, S., \& Setiawati, E. (2018). Pengetahuan dan Dukungan Sosial Mempengaruhi Perilaku Deteksi Dini Kanker Servik Metode Iva. Indonesian Journal of Midwifery (IJM), 1(1). https://doi.org/10.35473/ijm.v1i1 .34

Widiyanti, M. (2013). Hubungan antara depresi, cemas dan sindrom koroner akut. SMF Psikiatri Fakultas Kedokteran Universitas Udayan. 